\title{
La idea de partido en España: de la ilustración a las Cortes de Cádiz (1783-1814)
}

\author{
Ignacio Fernández Sarasola \\ Universidad de Oviedo
}

\begin{abstract}
Partidos: Vientos encontrados de cuyo choque salen los pronunciamientos y motines; ellos arrastran las nubes políticas por el horizonte de la nación, hasta que a fuerza de comunicarles electricidad promueven con frecuencia furiosas tempestades. (Juan Rico y Amat, Diccionario de los políticos, 1855)
\end{abstract}

\section{Introducción}

Acostumbrados hoy en día al protagonismo de los partidos en la vida política apenas resulta imaginable su difícil proceso de gestación y sus orígenes marginales. Sin embargo, los tempranos obstáculos que tuvieron que superar estas asociaciones fueron más teóricos que fácticos. En efecto, la formación real de los partidos acabó imponiéndose como una necesidad para conjugar los intereses sociales y canalizarlos hasta el Estado, pero la percepción teórica de su conveniencia tardó en consolidarse. Precisamente este trabajo trata de centrarse en la última cuestión, es decir, en explicar no ya cómo surgieron los partidos, sino

${ }^{1}$ El presente artículo tiene como base un texto más extenso que, con el título «Los partidos políticos en el pensamiento español (1783-1855)», se ha publicado en la revista electrónica Historia Constitucional, núm. 1, junio de 2000 (http://constitucion.rediris.es/revista/hc/uno/indicel.html).

Cuadernos de Estudios del Siglo XVIII, núms. 8 y 9. Oviedo, Instituto Feijoo de Estudios del Siglo XVIII, Universidad de Oviedo, 1999 , págs. 81-102. 
cómo se concibieron. Un análisis, pues, no de los hechos, sino de las ideas, aunque aquellos y éstas se hallan, evidentemente, vinculados.

El rechazo o el desconocimiento sin más de la idea de partido fue una característica propia de los primeros estadios del Estado liberal, y respondió a su concepción filosófica (individualismo) y política (idea de voluntad general uniforme, contenido indisponible de las Constituciones...). Sin embargo, la Ilustración tuvo una imagen muy distinta de esas asociaciones, percatándose de su existencia e, incluso, de su necesidad. Esta circunstancia paradójica es perceptible en nuestro país, pero está necesitada de respuesta. Así, en tanto que en el siglo xvIII ya se hablaba de los partidos, en nuestro primer constitucionalismo - tan rico en teorizaciones político-constitucionales- estos resultan relegados, y las escasas referencias los mencionan en términos peyorativos, como sinónimos de «facción».

¿A qué se debe este cambio de mentalidad? Como se tratará de mostrar en las páginas siguientes, esta inflexión en la idea de partido respondió a las divergencias constitucionales que separaron el siglo XVIII y el XIX español, en especial respecto del concepto de Constitución. Puede adelantarse que la Ilustración española, con su concepto constitucional, percibió la realidad de los partidos en los países extranjeros (especialmente en Gran Bretaña), en tanto que el constitucionalismo de las Cortes de Cádiz optó bien por ceñirse a la realidad histórica nacional, bien por elaborar construcciones more geométrico, desconociendo la práctica institucional que había dado lugar en Gran Bretaña a los partidos políticos.

\section{La idea de partido en el constitucionalismo del siglo XVIII (1783-1800)}

\subsection{Ideologías y tendencias políticas en la ilustración española}

Como es de sobra sabido, el siglo xvIII supuso la apertura de España a las lumières, en buena medida patrocinada por Carlos III. La filosofía escolástica, tan influyente hasta entonces, se postergó (impulsada también por la expulsión de los jesuitas) en favor del iusnaturalismo racionalista que procedía esencialmente de los Países Bajos (Grocio, Heineccio), Suiza (Vattel), Francia (Domat, Burlamaqui) y Alemania (Wolff, Puffendorf). Otras teorías de tipo pactista (Hobbes y Spinoza) encontraron una mayor oposición por la radicalidad de sus planteamientos. Sin embargo, la renovación de la Teoría del Estado trajo consigo también, de manera indisoluble, la teorización sobre las formas de gobierno. En este punto los autores más influyentes provenían esencialmente de Francia (Voltaire, Montesquieu, Mably y Rousseau) y Gran Bretaña (Locke, Bolingbroke, 
Hume y Blackstone), aunque no faltaron aportaciones importantísimas de autores de otros países (el suizo De Lolme, el italiano Filangieri, o el norteamericano John Adams).

Si el ius naturale de cuño racionalista tenía un componente universal, las formas de gobierno, sin embargo, presentaban una gran variedad de especies que dejaban traslucir las obras extranjeras. La mentalidad racionalista de la ilustración chocaba con una imagen casuística de las formas de gobierno, de modo que trató de buscar modelos universalmente válidos. En este sentido, la «teoría de los climas» que popularizó Montesquieu (a pesar de ser muy anterior a él), suponía determinar el gobierno más adecuado a partir de condicionantes geofísicos. Pero incluso se pretendió la existencia de un modelo que trascendiera estos condicionantes; un modelo tan universalmente válido como el Derecho Natural: el sistema de balanced constitution. Este modelo «teórico» hallaría un ejemplo «práctico» en Inglaterra. Si Polibio había visto en Roma el modelo de un gobierno «mixto» y equilibrado 2 , en el siglo xvIII, Voltaire, Montesquieu y Blackstone, entre otros, trataron de poner a Gran Bretaña como ejemplo del mismo $^{3}$.

No es de extrañar, por tanto, que en el siglo XvIII español, en el que se conocieron estas obras extranjeras, empezaran a difundirse Tratados sobre las formas de gobierno. Inicialmente la mayoría de estos Tratados tenía un carácter moderado, a fin de no enfrentarse al gobierno absoluto de Carlos III. Las obras de Ibáñez de la Rentería, o de Cabarrús, teorizan a un nivel abstracto sobre las formas de gobierno, pero siempre prefieren para España lo que ya existe; una Monarquía pura, apoyada por Consejos ${ }^{4}$. Sin embargo, poco a poco comienza a surgir un ala más liberal, que hacía suyas las premisas de los pensadores extran-

\footnotetext{
${ }^{2}$ Polibio, Histoires, edición de Raymond Weil, Paris, Société d'Édition «Les Belles Lettres», 1977, Libro VI, § III-IV (págs. 71-72), § x (págs. 80-81), § xI-XVIII (págs. 82-94).

${ }^{3}$ Voltaire, Lettres philosophuques (1734), Lettre VIII: Sur le Parlement, Gallimard, Paris, 1986, págs. 66 y 67; Charles de Secondat, Baron de Montesquieu, De l'espirit des lois (1748), Livre xi, Chapitre vi, Paris, Garnier Flammarion, 1979, vol. I; William Blackstone, Commentaries on the Laws of England (1765-1769), Book I, edición facsimilar de la primera edición (Oxford at the Clarendon Press, 1765), New York, William S. Hein \& Co., 1992. Hay que señalar, no obstante, que en Francia antes que Voltaire ya se había fijado en el gobierno británico Fénelon, aunque no lo mencionase directamente, sino que lo disfrazase bajo el utópico gobierno de Minos. Cfr. Francesco Salignac de la Mothe Fénelon, Les Aventures de Télémaque (1699), Paris, Gallimard, 1995, pág. 97.

${ }^{4}$ Conde de Cabarrús, Cartas sobre los obstáculos que la naturaleza, la opinión y las leyes oponen a la felicidad pública (1795), Madrid, Fundación Banco Exterior, 1990, especialmente págs. 41 y 46; José Agustín Ibáñez de la Rentería, Reflexiones sobre las formas de gobierno (1783), en Javier Fernández Sebastián (ed.), La Ilustración política, Bilbao, Servicio Editorial de la Universidad del País Vasco, 1994, pág. 166. En contra de la idea de Cabarrús como partidario del Despotismo Ilustrado se manifestó el profesor Maravall quien opinaba que, en realidad, Cabarrús era un «demócrata» (sic), a medio camino entre la Ilustración y el Liberalismo. Vid. José Antonio Maravald, "Cabarrús y las ideas de reforma política y social en el siglo XVIII, en Estudios de la Historia del Pensamiento Español (Siglo XVIII), Madrid, Mondadori, 1991, págs. 82 y sigs.
} 
jeros más radicales, como Locke, Sidney, Mably y, sobre todo, Rousseau, quien ya gozaba de fama por su Émile y La Nouvelle Héloüse. La formación de un pensamiento más rupturista y permeable a lo extranjero (baste pensar en Manuel de Aguirre o en León de Arroyal) y, lo que era más significativo, con una conciencia poco compatible con el catolicismo (especialmente las ideas deístas provenientes del enciclopedismo), hizo surgir un grupo antagónico, defensor de la identidad nacional, que recibió el calificativo de «apologistas» y a cuya cabeza figuraba Forner5.

Sin embargo, reformistas y apologistas lidiaron sus batallas sin una auténtica conciencia de grupo. Ninguno se refirió al contrario como un «partido»; eran meros desencuentros ideológicos sin más trascendencia política. En España no se daban las condiciones adecuadas para proponer la existencia de los partidos: no existía un pluralismo religioso como en Inglaterra, donde éste había sido determinante para la aparición de los partidos, y tampoco había instituciones representativas en las que poder manifestar las discrepancias ideológicas. Ello no obstante, ya en el siglo XVIII se encuentran las primeras menciones a los partidos, si bien circunscritas a realidades distintas de la española.

En efecto, estas primeras señas sobre los partidos no se referían al «deber ser», no proponían estas asociaciones como elementos necesarios, ni tan siquiera convenientes para España, cuya realidad era poco apta para admitirlos. Se trataba, por tanto, de alusiones a los partidos desde una perspectiva descriptiva, como realidades ajenas a nuestro país. En concreto, inicialmente los partidos se vieron como elementos característicos del régimen británico; más tarde también se tuvo conciencia de que estaban presentes en Francia y en Estados Unidos, aunque identificados como «facciones». A la percepción inicial de los partidos contribuyó la idea de Constitución que postulaban los intelectuales españoles del siglo XVIII. En efecto, antes de la Constitución norteamericana de 1787 y, sobre todo, de la Constitución francesa de 1791, en España se seguía el concepto aristotélico de Constitución, equivalente a régimen social, económico y político $^{6}$. Esto permitió concebir a los partidos como elementos sociopolíticos característicos de otras «Constituciones», o lo que es lo mismo, instituciones Real, 1786.

${ }^{6}$ Sobre este concepto de Constitución nos remitimos a la clásica obra de Charles Howard Mcilwain, Constitucionalismo antiguo y moderno, Madrid, Centro de Estudios Constitucionales, 1991. Hay que señalar una excepción muy temprana al concepto aristotélico de Constitución. Nos referimos al proyecto constitucional en sentido racional-normativo de Manuel de Aguirre publicado en el Correo de Madrid en 1787, aunque elaborado el año anterior, esto es, antes incluso de la aprobación de la Constitución Federal de Estados Unidos. La influencia de Manuel de Aguirre fue, sin duda, las cartas coloniales norteamericanas. Cfr. Antonio Elorza, «La excepción a la regla: reaccionarios y revolucionarios en torno a 1789», en La modernización política de España, Madrid, Ediciones Endymion, 1990, pág. 88. El cambio de concepto aristotélico de Constitución 
integrantes del entramado del régimen político-social de Gran Bretaña. Su aplicación a España, por tanto, no se planteaba, puesto que aquí la «Constitución» era muy distinta.

\subsection{Los partidos como necesidad de la forma de gobierno republicana}

La primera referencia extensa de los partidos se halla en la obra de Ibáñez de la Rentería Reflexiones sobre las formas de gobierno (1783), en la que seguía muy de cerca las teorías plasmadas por Montesquieu en su De l'Esprit des lois. Ibáñez de la Rentería, que todavía utilizaba un concepto aristotélico de Constitución ${ }^{7}$, analizaba la tradicional clasificación de las formas de gobierno (monárquico, y republicano, que a su vez se subdividía en aristocrático y democrático $^{8}$ ), acudiendo a los factores geofísicos para determinar su aplicación a uno $\mathrm{u}$ otro territorio. La presencia de los partidos era una característica en concreto de una de esas formas de gobierno, la democrática. Siguiendo a Montesquieu, el bilbaíno entendía que el gobierno democrático podía estar condenado a la parálisis. Su activación dependía, por tanto, de la existencia de determinadas asociaciones, que podían ser «partidos» o «facciones».

Es notable que ya en el siglo xviII Ibáñez de la Rentería establezca esta distinción. Para el ilustrado vasco, los partidos eran «movimientos secretos» dirigidos por quienes aspiraban al gobierno, y orientados a obtener los votos del pueblo que les permitiesen acceder a las Asambleas9. La perspicacia del análisis de Ibáñez de la Rentería le hizo percibir, pues, estas asociaciones tanto fuera como dentro del Parlamento, algo que luego no se repetiría hasta bien entrado el siglo XIX. Los partidos, absolutamente indisociables de las «constituciones republicanas» según Ibáñez de la Rentiría ${ }^{10}$, eran muy positivos en las democracias puesto que, como ya se ha dicho, permitían activar el gobierno. Sin embargo, perdían su virtualidad cuando concurría alguna de las siguientes cir-

por el concepto racional-normativo a partir de la independencia norteamericana puede apreciarse en Jovellanos. Vid. al respecto, Ignacio Fernández Sarasola, «Estado, Constitución y forma de gobierno en Jovellanos», Cuadernos de Estudios del Siglo XVIII, núms. 6 y 7, 1996-1997, págs. 93 y sigs.

${ }^{7}$ Cfr. Javier Fernández Sebastián, «Estudio introductorio: Ibáñez de la Rentería y el pensamiento político de la Ilustración», en La ilustración política, op. cit., págs. 83-84. El profesor Fernández Sebastián matiza, no obstante, que el concepto racional-normativo ya empieza a aparecer tímidamente en el texto de Ibáñez de la Rentería. En ocasiones Ibáñez de la Rentería utiliza el concepto historicista de «leyes fundamentales», y de hecho, en el capítulo titulado Gobierno legítimo en general. Leyes, llega a definirlas como aquéllas que «arreglan la forma del Estado y son, por decirlo así, sobre el mismo Legislador, no pudiendo o no debiendo éste tocarlas, porque de ellas recibe la investidura de tal». José Agustín Ibáñez dE LA RENTERía, Reflexiones sobre las formas de gobierno (1783), op. cit., pág. 165.

${ }^{8}$ Ibídem, pág. 159.

${ }^{9}$ Ibídem, pág. 181. Para Ibáñez de la Rentería una democracia no podía gestionarse sin la presencia de una Asamblea representativa de la Nación. Ibídem, págs. 177-178.

${ }^{10}$ Ibídem, pág. 181. 
cunstancias: la prevalencia del interés particular sobre el general, el ascenso de sujetos faltos de ilustración o movidos con intenciones perniciosas, lo que supondría una administración nociva, y, en fin, cuando el número de partidos era excesivo, lo que implicaba de nuevo la parálisis del Estado, propia también de la democracia que carecía de partidos ${ }^{11}$.

Por su parte, las «facciones» eran grupos que accedían de forma violenta al poder, mediante un ataque que trastocaba la misma Constitución ${ }^{12}$. En definitiva, Ibáñez de la Rentería concebía los partidos no sólo como algo positivo, sino incluso necesario cuando el Estado era democrático, y siempre que no se corrompiesen, o su número fuese tal que dispersase la capacidad decisoria, condenando la República a una parálisis. Por el contrario, las «facciones», consideradas como grupos de carácter «revolucionario», sólo podían calificarse de nocivas para la Constitución y el Estado. Ahora bien, no debe olvidarse que el bilbaíno entendía que la Constitución española era Monárquica, y que la Monarquía «pura» era la única forma de gobierno compatible con el Estado español, con extensas propiedades territoriales ${ }^{13}$; de hecho, Ibáñez de la Rentería no apreciaba ni tan siquiera el valor de los «cuerpos intermedios» que pudiesen «templar» la Monarquía convirtiéndola en «mixta» ${ }^{14}$. En consecuencia, los partidos no eran aplicables a la realidad española, poseedora de una «Constitución monárquica pura». Parece más bien que el autor estuviera pensando en el gobierno británico que, al menos en cuanto a la presencia de una Cámara Legislativa, tenía un componente «democrático».

Precisamente Gran Bretaña fue, directa o indirectamente, la fuente de la que Ibáñez de la Rentería extrajo su idea del partido. En efecto, Bolingbroke ya había distinguido entre el «partido del país» y el «partido de la corte». El primero debía representar la opinión pública nacional, unificada bajo el patrocinio de un «Rey patriota», situado por encima de los intereses parciales ${ }^{15}$. El

\footnotetext{
${ }^{11}$ Ibídem, págs. 181 y 182.

12 Idem.

${ }^{13}$ Ibídem, pág. 171.

${ }^{14}$ Cfr. Javier Fernández Sebastín, "Estudio introductorio: Ibáñez de la Rentería y el pensamiento político de la Ilustración», op. cit., pág. 91.

${ }^{15}$ Cfr. Henry St. John Bolingbroke, The idea of a Patriot King (1738), en The Works of Lord Bolingbroke in four volumes, vol. II, New York, Reprints of Economic Classics, 1967 (reimpresión de la edición de Henry G. Bohn, London, 1844), especialmente págs. 401-416. Bolingbroke diferenciaba entre «partido», que era un mal en sí mismo, y «facción», que constituía el peor de los partidos. Cuando el Rey se sumaba a un partido, éste asumía el carácter de facción, convirtiéndose en un poder despótico. En su Dissertation upon parties, Bolilngbroke insistía en la diferencia entre facción y partido, considerando que la primera suponía la prevalencia de los intereses personales. Cfr. Henry St. John Bolingbroke, A Dissertation upon Parties (1733-1734), en ibídem, vol. II, pág. 11. Precisamente en esta obra distinguía entre el «Cour party» y el «Country Party». Vid. ibídem, Letter I, págs. 26, 27; Letter III, págs. 37, 41; Letter v, pág. 51; Letter vi, pág. 61; Letter vis, pág. 67.
} 
«partido de la Corte», por su parte, no era sino una «facción», que no representaba al país, sino las ambiciones de determinados grupos, y que en Inglaterra estaba representado por los seguidores whig de su adversario político, Robert Walpole $^{16}$. Para el inglés, por tanto, el único partido admisible era el que no servía a intereses y ambiciones particulares, sino al «interés general» del país ${ }^{17}$; una idea en lo que se aprecia la huella de los opúsculos anteriores de Toland ${ }^{18}$. Las ideas de Bolingbroke influyeron en Voltaire, quien en la Encyclopedie redactó las voces «facción» y «partido», aunque la confusión entre ambos conceptos resultaba bastante patente ${ }^{19}$. Otro francés influido por Bolingbroke, Montesquieu, en el Libro XIX, Capítulo XXVII del Espíritu de las Leyes describía el gobierno británico en términos más reales que en el célebre Libro XI, Capítulo VI, percibiendo - eso sí, de manera muy tenue - la existencia de dos partidos, integrados por los defensores del Poder Legislativo, y los partidarios del Poder Ejecutivo $^{20}$. Finalmente, David Hume, que utilizaba los términos factions y parties indistintamente, había distinguido sin embargo entre «partidos o facciones de interés», asociaciones perniciosas unidas por intereses parciales, y las «facciones o partidos de principio», asociaciones positivas vinculadas por principios generales $^{21}$.

Sin duda Ibáñez de la Rentería conocía estas fuentes total o parcialmente, y de ellas no sólo heredaría la distinción entre partido y facción, sino también la idea de que el partido debía representar el interés general, y no la voluntad corrupta de intereses parciales. Ahora bien, al identificar partido e interés nacional, entendido en un sentido unitario, lo cierto es que el partido político no podía ser en realidad expresión de un pluralismo político. De hecho, como se ha seña-

\footnotetext{
${ }^{16}$ Sobre este punto vid. el reciente estudio de Joaquín Varela Suanzes, «El debate constitucional británico en la primera mitad del siglo xVIII: Bolingbroke vs. Walpole», Revista de Estudios Políticos, núm. 107, 2000.

${ }^{17}$ La distinción de Bolingbroke entre "partido» y «facción» se halla en Henry St. John Bolingbroкe, The Idea of a Patriot King (1738), op. cit., págs. 401, 402, 405 y 412.

${ }^{18}$ Cfr. John Toland, The Art of governing by Partys (1701), en J. A. W. Gunn (edit.), Factions no more. Attitudes to Party in Government and Opposition in Eighteen Century England, op. cit., págs. 50-52. «Nada puede menguar más a un Rey que el liderar un partido", afirmaba Toland. Sin embargo, Toland no partía de una idea totalmente negativa de los partidos, como puso de manifiesto Daniel Defoe: Daniel Defoe, On Government by Parties (1723), en ibídem, pág. 86.

${ }^{19}$ Cfr. Mario A. Cattaneo, Il partito politico nel pensiero dell'Illuminismo e della Rivoluzione Francese, op. cit., págs. 11 y sigs.

${ }^{20}$ Charles de Secondat, Barón de Montesquieu, De l'esprit des lois (1748), Garnier-Flammarion, Paris, 1979, vol. II, Livre xIx, Chapitre xxvII, págs. 478-479.

${ }^{21}$ Cfr. David Hume, Of parties in general (1741), en David Hume, Essays moral, political and literary, edición de T. H. Green y T . H. Grose, Aalen, Scientia Verlag, 1964 (reimpresión de la edición de London, 1882), vol. I, Essay VIII, págs. 127-133. Sobre la idea de Hume sobre los partidos vid. Joaquín Varela SuanzEs, Sistema di governo e partiti politici nel pensiero britannico da Locke a Park, Manduria/Roma, Piero Lacaita, 2000 (en prensa).
} 
lado, el número «excesivo» de partidos supondría un defecto de la Constitución republicana.

\subsection{Inglaterra y los partidos ministerial y de oposición}

También de Gran Bretaña, y en su Constitución de sentido aristotélico, se ocupó en fechas tempranas Victorián de Villava, para apreciar en este país la presencia de partidos. Villava mencionó por vez primera la existencia en Gran Bretaña de dos partidos distintos en atención al apoyo al Gobierno: un partido ministerial, formado por los empleados designados por los ministros para defender su causa, y un partido que permanecería a la sombra, oponiéndose a sus medidas $^{22}$. Ahora bien, los integrantes de este último partido no sólo actuaban como oposición por resentimiento, sino que podía existir en ellos un auténtico «amor a la patria». De esta forma, la «oposición» (aunque todavía no utilizaba este nombre) podía ser útil al país, erigiéndose en guardián de las libertades. Para Villava los partidos tenían en todo caso un efecto beneficioso para la constitución, a través de la lucha ministerio-oposición, que daba mayor vitalidad a la Constitución: "Los continuos debates de los partidos — decía—, lejos de debilitar la constitución, la fortifican ${ }^{23}$.

Otro de los grandes escritores políticos del siglo XVIII, León de Arroyal, mencionó los partidos en sus Cartas al Conde de Lerena. En la primera serie de estas cartas, León de Arroyal utilizaba un concepto aristotélico de Constitución, que a partir de 1791 cambiaría por el concepto racional-normativo. La referencia a los partidos se halla precisamente en la primera serie epistolar, de modo que León de Arroyal describía los partidos como realidades insertas en un régimen determinado, el inglés. El ilustrado ya en otros escritos había expresado su admiración por el régimen de libertades inglés ${ }^{24}$, y en las Cartas subrayaba precisamente la contribución que habían hecho los "partidos de oposición» a este régimen, hasta el punto de considerarlos como la "principal fuente de la felicidad inglesa» 25 .

\footnotetext{
${ }^{22}$ Victorián de Villava, Apéndice a la traducción de las Lecciones de comercio o bien de economía civil del abate Antoinio Genovesi, catedrático de Nápoles, traducidas del italiano por Don Victorián de Villava, Colegial del Mayor de San Vicente Mártir de la Universidad de Huesca y Catedrático de Código de la misma (1784), en la recopilación de textos realizada por Ricardo Levene, Vida y escritos de Victorián de Villava, Buenos Aires, Peuser, 1946, pág. XXII.

${ }^{23}$ Idem.

${ }^{24}$ Léon de Arroyal, Pan y toros (Oración apologética en defensa del estado floreciente de España) (redactado hacia 1792, y publicado en 1812), en Antonio Elorza (ed.), Pan y toros y otros papeles sediciosos de fines del siglo XVIII, Madrid, 1971, Ayuso, pág. 31.

${ }^{25}$ León de Arroyal, Cartas econócmico-políticas, Universidad de Oviedo, 1971, Parte I, Carta IV, 13 de julio de 1789 , pág. 81 .
} 
La diferencia esencial entre Ibáñez de la Rentería y León de Arroyal (a pesar de su idéntica percepción de los partidos como realidades de la Constitución material inglesa) reside en que para el segundo el partido que servía a la libertad no era el que representara un interés general, sino precisamente el partido de «oposición», el que no ejercía el poder público. En realidad, esta diferencia respondía a la discrepancia de fondo entre ambos autores acerca de la forma de gobierno más idónea. Ibáñez de la Rentería, moderado en sus planteamientos, consideraba que el régimen más idóneo era la Monarquía; la democracia tendía al asambleísmo, y sólo era positiva cuando había un partido que representara ese «interés general» (o «felicidad pública», término ilustrado que utilizaba con más asiduidad ${ }^{26}$ ) que en una Monarquía personificaba el Rey. En un sistema «mixto», como el británico, no tardaría en manifestarse la confrontación entre el elemento monárquico y democrático si no existía una comunión de intereses entre ambos. Por tanto, el partido político que accediese al Parlamento tan sólo era intrínsecamente bueno cuando portara el mismo interés general que el titular de la Corona. León de Arroyal, por el contrario, mostraba un ideario mucho más liberal, aun cuando todavía no hubiese llegado a las teorías del poder constituyente y la consiguiente idea de Constitución racional-normativa. Para León de Arroyal, el Monarca y sus ministros tendían a la opresión de las libertades; por consiguiente, sólo un partido «opositor» al Gobierno podía servir de contrapeso y salvaguardia de los derechos de la nación. En definitiva, la concepción de los partidos de Ibáñez de la Rentería y de Arroyal ya mostraban en el fondo dos formas de concebir la Monarquía y sus relaciones con el Legislativo que después se mantendrán en las Cortes de Cádiz.

\subsection{Repercusión de las revoluciones americana y francesa sobre la imagen de partido: los partidos como facciones}

A partir de la Revolución Francesa, las manifestaciones en España sobre los partidos cobran un nuevo cariz. Los excesos de los jacobinos hicieron que se viese con recelo la formación de grupos políticos en el Estado, ya que tendían a protagonizar movimientos revolucionarios y sediciosos. Si hasta entonces se hablaba de partido como algo positivo, diferenciado de facción, desde la Revolución Francesa se habla fundamentalmente de esta última, o se identifican sin más ambos conceptos, siempre con significado peyorativo. Del «buen ejemplo» de Inglaterra se pasó al «pésimo ejemplo» de Francia e incluso de Estados Unidos. Algo que no debe extrañar, puesto que muchos de los ilustrados espa-

${ }^{26}$ Cfr. Javier Fernández Sebastián, «Estudio introductorio: Ibáñez de la Rentería y el pensamiento politico de la Ilustración», op. cit., pág. 60. 
ñoles que hasta entonces habían admirado el progreso de las luces en general se replantearon su postura a raíz del magno acontecimiento del país vecino y, sobre todo, tras la ejecución de Luis XVI.

En su análisis político sobre la situación de Francia, Campomanes apreció la división nacional en tres partidos: asambleístas (o constitucionalistas), realistas y jacobitas. Los primeros defendían una Constitución (ahora ya entendida en sentido racional-normativo) que había destruido totalmente el antiguo sistema $^{27}$, y que los otros «partidos» rechazaban de plano ${ }^{28}$. Todo ello ponía de manifiesto que se habían formado facciones contradictorias y opuestas "que mutuamente se contrarían y cada una de ellas aspira a oprimir a las otras dos ${ }^{29}$, lo que demostraba lo pernicioso que era esta «disociación», que daba lugar a excesos revolucionarios. A la crítica de Campomanes a los partidos franceses todavía subyacía la defensa de una concepción constitucional histórico-aristotélica: la iniquidad de los partidos de la nación vecina venía corroborada por el hecho de que su presencia había acabado por derruir la Constitución material asentada en siglos de historia, para sustituirla por una obra nueva.

La identificación entre partido y facción se manifiesta incluso entre las filas liberales españolas, como en Valentín de Foronda. Éste mostraba ya un pensamiento abiertamente liberal, considerando en 1788 que las fuentes de la felicidad nacional eran los derechos de propiedad, libertad, seguridad e igualdad $^{30}$. Sin embargo, en 1804, describiendo el régimen norteamericano denunciaba la excesiva heterogeneidad político-social, la gran cantidad de «demócratas», «federalistas»y «sectas» que, apoyados en un ejercicio abusivo de la libertad de imprenta, acabarían por provocar una revolución que ya estaba latente ${ }^{31}$. El rechazo de Foronda a los partidos, tal y como los veía en Estados Unidos, coin-

${ }^{27}$ Pedro Rodríguez Campomanes, «Reflexiones sobre la política exterior» (1792), en Inéditos Políticos, Oviedo, Junta General del Principado de Asturias, 1996, págs. 177 y 184; id., "Segundas observaciones sobre el sistema general de Europa» (1792), en ibídem, págs. 190-191 y 220-222; "Terceras observaciones y una nota sobre el sistema general de Europa» (1792), en ibídem, págs. 272-273.

${ }^{28}$ Los realistas la rechazarían por atentar contra el Trono, y los jacobitas por la extensión otorgada al poder ejecutivo y porque deseaban «la democracia absoluta o, por mejor decir, la anarquía ilimitada». Idem.

${ }^{29}$ Pedro Rodríguez Campomanes, «Segundas observaciones sobre el sistema general de Europa» (1792), op. cit., pág. 220 .

${ }^{30}$ Valentín de Foronda, Cartas sobre los asuntos más exquisitos de la Economía Política y sobre las leyes criminales (1788), Pamplona, Imprenta de Ramón Domingo, 1821, pág. 4. Estas ideas las reprodujo en 1809, en sus Apuntes ligeros sobre la nueva Constitución (Filadelfia, 1809). El texto en: Adolfo de Castro, Cortes de Cádiz. Complementos de las sesiones verificadas en la Isla de León y en Cádiz, Madrid, Imprenta de Prudencia Pérez de Velasco, 1913, vol. I, págs. 71 y sigs. En idéntico sentido en una obra suya publicada de forma anónima: Carta sobre el modo que tal vez convendría a las Cortes seguir en el examen de los objetos que conducen a su fin, y dictamen sobre ellos, Cádiz, 1811, Imprenta de D. Manuel Ximénez, pág. 15.

${ }^{31}$ Valentín de Foronda, Apuntes ligeros sobre los Estados Unidos de la América Septentrional (1804), en M. Benavides/C. Rollán, Valentín de Foronda: los sueños de la razón, Madrid, Editora Nacional, 1984, págs. 436 y 437. 
cidía con la opinión que de éstos tenía James Madison, quien en The Federalist había cargado tintas contra las «facciones» y el «espíritu de partido», al que sólo una unión bien organizada podría contener ${ }^{32}$.

Así, desde Ibáñez de la Rentería hasta Campomanes y Valentín de Foronda, los partidos se consideraban facciones cuando su número era excesivo, dando lugar a confrontaciones violentas y a un clima inestable que amenazaba convertirse en revolución. Inglaterra parecía quedar a salvo de estas críticas, destinadas a Francia y Estados Unidos. Albión no sólo mostraba a España la bondad de su forma de gobierno, sino también de su régimen político. Y es que, en el fondo, el equilibrio constitucional entre Rey y Parlamento se reproducía con el bipartidismo inglés, donde whigs y tories aparecían como contrafuerzas que equilibraban el sistema garantizando la libertad.

\section{La idea de partido en el constitucionalismo gaditano (1808-1813)}

\subsection{Discrepancias ideológicas: liberales, serviles y afrancesados}

La Guerra de la Independencia supuso una escisión en dos grandes frentes: el afrancesado y el «patriota» (según la denominación de la época). Durante la contienda se denominó como «afrancesados» a aquellos que se habían adscrito a la causa de Napoleón y José I, pero con posterioridad una visión más objetiva permitió diferenciar entre, por una parte, los «afrancesados» (portadores de una ideología heredera del enciclopedismo y de la fisiocracia y que se veía satisfecha con la reforma administrativa propuesta por Napoleón), y por otra, los meros «juramentados» que habían jurado obediencia a José I por motivos diversos, no siempre ideológicos ${ }^{33}$.

Los «patriotas» tenían como elemento común el reconocimiento de Fernando VII como legítimo Monarca de España y el consiguiente rechazo hacia José I. Pero, más allá de esta comunión de interés, las discrepancias ideológicas de este sector eran profundas: por una parte, existía un grupo liberal, fundamentalmente influido por las doctrinas derivadas de la Revolución Francesa; por otra, los absolutistas o «serviles», denominación que durante la Guerra de la Independencia se utilizó para designar despectivamente a los partidarios del poder absoluto

${ }^{32}$ Cfr. James Madison, The Federalist, núm. 10, 22 de noviembre de 1787, en Alexander Hamilton / James MAdison / John JAY, The Federalist, edición a cargo de Jacob E. CoоKe, Maddletown, Wesleyan University Press, 1989, págs.56-65.

${ }^{33}$ Entre la doctrina ha puesto de manifiesto esta distinción Miguel Artola, Los afrancesados, Madrid, Turner, 1976, págs. 52 y sigs. Puede consultarse también Jean-René Aymes, Los españoles en Francia (18081814), Madrid, Siglo XXI, 1987. 
de Fernando VII. La discrepancia radical entre estos dos grupos impedía en esos momentos reconocer la autonomía de otro grupo, realista ilustrado, caracterizado por un talante moderado, inclinado hacia el sistema británico de gobierno y partidario de una reforma constitucional, en vez de acometer un nuevo proceso constituyente.

A esta división tripartita del sector patriota hubo de sumarse un cuarto grupo en el momento de reunirse las Cortes de Cádiz: el integrado por los diputados americanos. Los planteamientos de este grupo solían estar próximos a los liberales (así, por ejemplo, en Mejía Lequerica, Larrazábal, Ramos de Arispe), con los que se agruparon en no pocas ocasiones para votar las medidas constitucionales. Sin embargo, discrepaban en las cuestiones relativas al tratamiento de los territorios de Ultramar. Los americanos, a partir de una idea de Nación en la que se mezclaban el elemento provincial y el individualista, defendieron con denuedo la igualdad de representación en toda la Monarquía española; algo que contó con la oposición tanto de los liberales de la metrópoli como de los realistas ${ }^{34}$.

A pesar de que cada uno de los grupos descritos (afrancesados, liberales, absolutistas, realistas y americanos) contaban con un ideario bastante definido, durante la Guerra de la Independencia no se autoproclamaron como partidos ${ }^{35}$. El uso del término "partido» estuvo muy poco extendido durante la Guerra de la Independencia. Según se ha visto, en la última mitad del siglo xvIII el «partido» tuvo una connotación positiva, concebido como una realidad de la constitución material inglesa. Los partidos mostraban su cara negativa cuando eran excesivos, identificándose entonces con facciones. Tal era la situación de Francia desde la Revolución, y de Estados Unidos. Ahora bien, con la Guerra de la Independencia la imagen positiva del partido desaparece totalmente. Es más, las referencias mismas al partido son muy escasas. Del reconocimiento como realidad extranjera se pasó a la ignorancia casi total del partido. Es significativo, por ejemplo, que Jovellanos, tan atento al régimen inglés, no les dedicase una sola palabra, a pesar de que tendría que conocer su existencia. Jovellanos vio

\footnotetext{
${ }^{34}$ Cfr. Joaquín Varela Suanzes, La Teoría del Estado en los orígenes del constitucionalismo hispánico (Las Cortes de Cádiz), Madrid, Centro de Estudios Constitucionales, 1983, págs. 175 y sigs.

${ }^{35} \mathrm{La}$ profesora Seoane recoge algunas excepciones procedentes de Valiente y Calatrava, que le inducen a considerar que existía un «espíritu de partido» entre realistas y liberales. Cfr. María Cruz Seodne, El primer lenguaje constitucional español: (Las Cortes de Cádiz), Madrid, Editorial Moneda y Crédito, 1968, págs. 171-172. Quintana, por su parte, llegó a afirmar que en Cádiz sólo habían existido dos partidos; los partidarios de la «monarquía constitucional» y los que deseaban la monarquía absoluta. La limitación regia era, pues, el único criterio admisible para diferenciar "partidos». Vid. Manuel José Quintana, «Pensamientos», en Obras inéditas del exmo. Sr. D. Manuel José Quintana», Madrid, Medina y Navarro Editores, 1872, pág. 250.
} 
en Inglaterra un sistema de checks and balances, tal y como describían desde Montesquieu a Blackstone, y desde Adam Ferguson hasta David Hume, pero nunca mencionó los partidos ingleses, aun cuando se hallaba bien informado de los debates que se sustanciaban en la Cámara de los Comunes entre los líderes whig (Charles James Fox) y tory (William Pitt) de la Inglaterra de Jorge III; y aun cuando su gran amigo e informante del gobierno británico, Lord Holland, era un reputado whig $^{36}$.

En parte, esta ignorancia del partido responde a un cambio del concepto de Constitución. Como se verá enseguida, a comienzos del xIX se abandonó la idea aristotélica de Constitución, sustituyéndola por un concepto racional-normativo (liberales), o por un concepto histórico (realistas). La situación nacional hizo que los estudios abstractos sobre los regímenes políticos se postergasen en favor del análisis del gobierno más adecuado para España. No interesaba analizar las realidades extranjeras, sino aquellas que pudiesen tener aplicación en nuestro país. Los partidos, característicos de Inglaterra, no superaron esta criba: ni eran conformes con las expectativas liberales, ni resultaban compatibles con la Constitución histórica de los realistas.

Las escasas referencias a los partidos que se encuentran durante la Guerra de la Independencia los identifican con facciones, desapareciendo por tanto la dicotomía partido/facción. Toda división se consideraba nociva en un momento en que era preciso aunar las voluntades no sólo para derrotar a Napoleón, sino también para reformar la Monarquía española a fin de evitar ulteriores abusos. La situación política exigía, por tanto, negar los partidos. Así, el argumento de que los partidos disgregaban la voluntad nacional lo utilizó el Consejo de Castilla para oponerse a una reunión de Cortes en que estuviera representado el tercer estado más allá de lo dispuesto por la Constitución histórica. Unas Cortes así formadas, decía el Consejo de Castilla, "es expuesta a que se formen par-

\footnotetext{
${ }^{36}$ Sobre la idea de Jovellanos acerca de la Constitución británica vid. Joaquín Varela SuAnzes, «La doctrina de la Constitución Histórica: de Jovellanos a las Cortes de 1845», Revista de Derecho Político, núm. 39, 1995, págs. 45 y sigs.; Ignacio Fernández SARAsola, «Estado, Constitución y forma de gobierno en Jovellanos», op. cit., págs. 105 y sigs.; Clara Áldvarez Alonso, «La influencia británica y la idea de Constitución en Jovellanos", en Andrea Romano (editor), Il modello costituzionale inglese e la sua recezione nell'area mediterranea tra la fine del 700 e la prima metà dell'800, Milano, Giuffrè, 1998, págs. 507 y sigs. Sobre la importancia de Lord Holland en la figura de Jovellanos víd. Manuel Moreno Alonso, La generación española de 1808, Alianza, Madrid, 1989; Íd., «Sugerencias inglesas para unas Cortes españolas», en Juan Cano Bueso (edit.), Materiales para el estudio de la Constitución de 1812, Madrid, Tecnos, 1989, págs. 521 y sigs.; Íd., «Las «Insinuaciones» sobre las Cortes de John Allen», Revista de las Cortes Generales, núm. 33, 1994, págs. 238 y sigs.; Francisco Tomás y Valiente, "Las Cortes de España en 1809, según un folleto bilingüe cuya autoría hay que atribuir a un triángulo compuesto por un Lord inglés, un ilustrado español y un joven médico llamado John Allen», en A. IGLEsia (edit.), Estat, dret i societat al segle XVII. Homenatge al profesor Josep María Gay i Escoda, Barcelona, Associació Catalana d'Historia del Dret «Jaume de Monjuïc», 1996, págs. 771 y sigs.
} 
tidos y facciones que ocasionarían gravísimos males en el reino» ${ }^{37}$. En la «Consulta al País» ${ }^{38}$, el informante Bosmeniel apuntalaba su proyecto constitucional indicando que toda la Nación debía estar unida, superando todo tipo de partidismo $^{39}$. Y en las Cortes de Cádiz, el diputado por Guatemala Larrazábal decía que la igualdad representativa en toda la Nación (incluidos, pues, los territorios de Ultramar) era necesaria para evitar que surgiesen partidos en América $^{40}$.

Sin embargo, nada mejor que las palabras del periódico liberal La Abeja Española para poner de manifiesto la idea de partido presente durante la Guerra de la Independencia: "No hay partidos ni los puede haber donde exista una fuerza preponderante que los quiera disipar. Las fermentaciones políticas que excitan las mejoras ocasionan los partidos porque dan lugar al choque de los intereses, y los partidos producen obstinación ${ }^{41}$.

Esta imagen del partido como facción la sostuvo también Blanco White, a pesar de que su residencia en Londres le podía proporcionar un cabal conocimiento de los partidos políticos. A través de El Español, periódico que publicó en la capital inglesa, Blanco White buscó moderar el radicalismo de los diputados liberales. Su propuesta esencial era que se tomara como modelo el sistema de gobierno inglés, y no el revolucionario francés. Pero en este modelo británico Blanco White no daba acogida a los partidos. De hecho, según él, la mayor virtualidad de gobierno inglés, el bicameralismo, evitaba el influjo de las facciones en el procedimiento legislativo ${ }^{42}$. Esta postura de Blanco White

${ }^{37}$ Consulta del Consejo de Castilla a la Junta Central (Madrid, 8 de octubre de 1808), en Manuel FERnández Martín, Derecho Parlamentario español, Madrid, 1992, Publicaciones del Congreso de los Diputados, vol. I, pág. 414. Esta misma idea la sostuvo en las Cortes de Cádiz el realista Inguanzo: «Las Asambleas muy numerosas no son siempre las más reflexivas. Los partidos, la rivalidad, los interese particulares se cruzan fácilmente; las pasiones se exaltan, y si una facción domina, puede arrastrar a los demás y al Cuerpo entero a su ruina». Como ejemplo ponía, una vez más, el de la Francia de la Convención, dominada por «facciosos». DS (Cortes extraordinarias de 1810-1813), núm. 345, 12 de septiembre de 1811, vol. III, pág. 1825. En igual medida, otro realista, Borrull, afirmaba que el veto regio tenía por objeto impedir que en una asamblea numerosa las leyes fuesen obra de una facción. DS (Cortes extraordinarias de 1810-1813), núm. 811, 31 de marzo de 1813, vol. VII, pág. 4941.

${ }^{38}$ Se denomina así al conjunto de informes remitidos por instituciones y particulares a partir de un decreto de la Junta Central de 22 de mayo de 1809, por el cual convocaba a los estudiosos a proponer los medios necesarios para sostener la guerra y las reformas precisas para el Estado español. Los informes se han reproducido parcialmente en: Miguel ARtola, Los orígenes de la España contemporánea, Instituto de Estudios Políticos, Madrid, 1976, vol. II y en Federico Suárez, Cortes de Cádiz. Informes oficiales sobre Cortes, Pamplona, EUNSA, vol. I (1967); vol. II (1968) y vol. III (1974).

39 «Es necesario firmeza, y determinación positiva de sacrificar todos los partidos y todas las opiniones en el altar majestuoso de la Patria». Informe de Juan Bosmeniel y Riesco, La Habana, 29 de septiembre de 1809, Archivo del Congreso de los Diputados, Legajo 7, núm. 8.

${ }^{40}$ DS (Cortes Extraordinarias 1810-1813), núm. 359, 26 de septiembre de 1811, vol. III, pág. 1928.

${ }^{41}$ La Abeja Española, vol. vı, núm. 317, 25 de julio de 1813, pág. 201.

${ }^{42}$ El Español, vol. vi, enero de 1813, pág. 15. 
es comprensible porque en realidad, y a pesar de su cercanía a Gran Bretaña, no concebía el sistema de gobierno británico como un sistema parlamentario ${ }^{43}$ (con la importancia que tiene en éste la oposición ${ }^{44}$ ), sino que permanecía anclado en la anacrónica idea de balanced constitution, como demuestra su idea del poder regio fuerte, de responsabilidad exclusivamente penal de los ministros y su concepción de la cámara alta como cuerpo intermedio entre el Rey y el pueblo.

La Constitución de 1812, como es de sobra sabido, no respondió al modelo británico que proponía Blanco White, sino al francés de 1791. Según Blanco White, el resultado de establecer una Constitución novedosa, que no respetaba el pasado nacional, era dividir la población entre acólitos del documento constitucional y radicales opositores. La Constitución era incompatible con un espíritu conciliador, y daba lugar a una profunda división política, es decir, a «partidos» ${ }^{45}$. De este modo, el brillante liberal identificaba los partidos con facciones, desconociendo el importante papel del pluralismo político.

La negación de los partidos políticos durante la Guerra de la Independencia no sólo se debió a motivos de oportunidad política (a saber, necesidad de aglutinar voluntades contra Napoleón y en favor de las reformas), sino a una profunda convicción teórica. Liberales y realistas negaron el partido porque no era compatible con su idea de libertad, de Constitución y de forma de gobierno.

\subsection{La negación del partido en la sociedad: la idea de derechos y libertades}

La existencia de los partidos políticos no resulta posible, claro está, sin el reconocimiento más genérico del derecho de asociación que les sirve de fundamento. Sin embargo, este derecho no se halla presente en la Constitución de 1812, a pesar de haberse regulado en la Francia revolucionaria que le servía de modelo ${ }^{46}$. Alcalá Galiano, en su visión de la Guerra de la Independencia se

\footnotetext{
${ }^{43}$ Contra esta idea vid. Joaquín Varela Suanzes, «Un precursor de la Monarquía Parlamentaria: BlancoWhite y El Español (1810-1814)», Revista de Estudios Políticos, núm. 79, 1993, págs. 101 y sigs. El profesor Varela entiende que Blanco White sostuvo una embrionaria idea de gobierno parlamentario (a diferencia de la ideología asamblearia propia de los liberales de las Cortes de Cádiz), postulando una colaboración entre Legislativo y Ejecutivo, basada en el principio básico de compatibilidad de cargos.

44 Vid. por todos Georges Burdeau, "L'évolution de la notion d'opposition», Revue Internationale D'Histoire, Politique et Constitutionnelle, 1954, págs. 119-125.

${ }^{45}$ Así lo expuso en un artículo publicado en julio de 1813 bajo el emblemático título «Sobre las divisiones internas que empiezan en España» (El Español, vol. vII, julio de 1814, págs. 3-11). En septiembre del mismo año repetía que «España está dividida en dos partidos», los liberales y los serviles, caracterizados por la intolerancia política y la intolerancia religiosa, respectivamente. El Español, vol. viI, septiembre de 1813, págs. 149-150.

${ }^{46}$ La actitud inicial de los políticos franceses fue de reticencia hacia el derecho de reunión y asociación. Así, La Déclaration des Droits de l’Homme et du Citoyen, de 1789, no recogía este derecho. Los proyectos previos a tal declaración tampoco lo mencionaron: de los más de 50 proyectos que recoge Christine Fauré, apenas menciona el derecho de reunión el texto de Boislandy (art. 73). Vid. los documentos en Chris-
} 
percató de tal circunstancia: "mientras de la libertad de imprenta se habló mucho en la primera época constitucional -afirmaba-, en la de reunión apenas hubo quien pensase». Para el célebre publicista la omisión se habría debido a motivos de oportunidad política: el pernicioso ejemplo de los clubes franceses y el peligro de reconocer tal derecho en la sitiada ciudad de Cádiz, donde una reunión tumultuosa podía desembocar en motín ${ }^{47}$. Sin embargo, la negación de este derecho respondía también a razones teóricas. Liberales y realistas negaron el derecho de asociación (y con él los partidos) a partir de su particular concepción de los derechos y libertades.

Los realistas, como Inguanzo, Borrull o Alonso Cañedo, tenían una concepción organicista de los derechos, identificados como libertades propias de los distintos estratos sociales que integraban el reino. Estos derechos constaban en las Leyes Fundamentales, o Constitución rubricada por la historia, que expresaban el pacto suscrito entre el Rey y el Reino para regular las prerrogativas de aquél y los privilegios de éste. En realidad, las libertades se estructuraban en dos planos integrados: libertades del Reino (especialmente el derecho de reunirse en Cortes a partir del principio quod omnes tangit ad omnibus tractari de aprobari debent) y libertades de los distintos grupos que componían el Reino (esto es, libertades del clero, la nobleza y el pueblo llano, plasmadas especialmente en el derecho de cada uno de ellos a concurrir a las Cortes). Los derechos se concebían desde una perspectiva relacional; así, el Reino era titular de libertades frente al Rey, del mismo modo que cada grupo social poseía derechos frente a los restantes. Con ello se lograría un «estado mixto» que garantizaría el equilibrio constitucional indispensable para el Estado.

Cada grupo (y no cada individuo) era titular de determinados derechos (lo que suponía negar la igualdad formal). Ahora bien, ello no suponía optar por la más absoluta heterogeneidad en la titularidad y contenido de los derechos. Por el contrario, la uniformidad se lograba, por una parte, dentro de cada grupo y, por otra, a través de la integración de cada grupo en el Reino, unido por prin-

\footnotetext{
tine Fauré (edit.), Las declaraciones de los derechos del hombre de 1789, México, Fondo de Cultura Económica, 1995 (el texto de Boislandy en pág. 274). Otros rechazaban expresamente los «partidos» (J. L. Seconds, en ibídem, pág. 55) y el «espíritu de grupo» (Malouet, en ibídem, pág. 142). La Constitución de 1791, sin embargo, sí recogió el derecho de reunión en su Título I, art. 3, al igual que lo haría la Constitución de 1793 en el artículo 7 de su Declaración de derechos. El líder jacobino Robespierre también fue partidario de este derecho, como demuestra el art. 5 de su propuesta de Declaración de Derechos. Vid. RobespierRe, «Sobre la propiedad y la Declaración de Derechos» (Discurso ante el Club de los Jacobinos, 9 de mayo de 1791), en Emilio Gilolmo/José Áluarez Junco (edit.), Los jacobinos, Madrid, Edicusa, 1970, pág. 159.

47 Antonio Alcalá Galiano, Recuerdos de un anciano, en Obras escogidas, B.A.E., vol. LXxxiII, tomo I, Madrid, Atlas,1955, pág. 149. Un breve análisis de la regulación normativa de los derechos de reunión y asociación en España en Rafael FlaqueR Montequi, «El derecho de asociación, reunión y manifestación», en Rafael Flaquer Montequi (ed.), Derechos y Constitución, Ayer, núm. 33, 1999, págs. 155 y sigs.
} 
cipios comunes (tales como el respeto a la Monarquía o a la religión, auténtico límite del ejercicio de los derechos). Así, los realistas no admitían divisiones internas dentro de cada grupo social. Sólo era admisible la estratificación social determinada por la Constitución histórica, pero no la formación de nuevas asociaciones cuyos miembros defendiesen intereses distintos a los propios de su grupo social. El resultado sólo podía ser la negación de los partidos, considerados como asociaciones contrarias a la pétrea organización estamental.

El concepto liberal de las libertades era muy distinto, pero traía igualmente como consecuencia el rechazo del derecho de asociación. Los liberales, como Toreno, Gallego o Argüelles, partían de las teorías del estado de naturaleza y del pacto social (por más que razones políticas les obligaran a disfrazarlas bajo un ropaje historicista $)^{48}$ y, por consiguiente, de la plena igualdad de los derechos civiles (aunque no de los políticos) ${ }^{49}$. La sociedad nacía de un pacto de asociación, pero éste sólo se había celebrado por una «necesidad absoluta», siguiendo una terminología leibiniziana, es decir, por la inviabilidad de garantizar los derechos en el estado de naturaleza. Del pacto social nacía una asociación unitaria que tenía por objeto exclusivo satisfacer las libertades de sus miembros por encima de los intereses egoístas.

Por tanto, el reconocimiento del derecho de asociación habría chocado contra la finalidad misma del pacto social, al dar de nuevo cabida a intereses parciales. En definitiva, las asociaciones colisionaban frontalmente con la Asociación, dando lugar a pactos sociales dentro del Estado, o lo que es lo mismo, a sub-Estados. El principio asociativo por tanto era una necesidad (y no un derecho) del estado de naturaleza que no podía hallarse en el estado de sociedad (donde esta necesidad ya se había paliado) sin peligro de que esta última se descompusiese. Las asociaciones atomizarían la unidad lograda con el pacto social, dando lugar a un nuevo Estado que ni sería un verdadero Estado (por la

${ }^{48}$ Como reconoce hoy de forma casi unánime la doctrina, el ropaje historicista tenía por objeto tan sólo esconder que las ideas liberales eran tributarias del pensamiento iusnturalista de impronta francesa. Los liberales pretendían con ello que no se les identificase con las ideas del enemigo nacional y, a la vez, tratar de disfrazar la ruptura del Antiguo Régimen con una pátina de «regreso al pasado nacional». La doctrina de los derechos naturales sólo la expusieron de forma abierta los diputados americanos que pretendían, precisamente, una ruptura con el pasado nacional para lograr el reconocimiento de mayores libertades para los territorios de Ultramar.

${ }^{49}$ Doctri nalmente esta distinción estaba plenamente justificada. Siguiendo las teorías de Locke y Paine, entendían que los derechos civiles no eran más que los derechos naturales que en sociedad se veían limitados por un poder público que garantizaría que no se emplearan en detrimento de los demás. Por tanto, los derechos subjetivos del estado de naturaleza transmutaban en derechos civiles una vez celebrado el pacto social, pero seguían teniendo una fundamentación iusnaturalista. Ahora bien, los derechos políticos no podían tener idéntica fundamentación por la lógica circunstancia que la participación política era impensable en el estado de naturaleza, donde no existía poder público. Las libertades positivas nacían, por tanto, exclusivamente del pacto social. 
presencia de grupos en su interior), ni tampoco un «estado de naturaleza» (porque no se compondría de individuos, sino de asociaciones). Su mayor parecido era con los grupos sociales característicos del Antiguo Régimen. Precisamente aquello contra lo que el liberalismo luchaba con mayor denuedo. Al rechazar las asociaciones, los liberales se adscribían a la negación rousseauniana de los cuerpos intermedios, yendo incluso más allá que el constitucionalismo francés, que sí había admitido el derecho de reunión y asociación.

\subsection{La incompatibilidad de los partidos con la Constitución racional- normativa y con la Constitución histórica}

Durante la Guerra de la Independencia el concepto aristotélico de Constitución se sustituyó definitivamente por los conceptos racional-normativo (utilizado por los liberales) e histórico (seguido por los realistas), lo que contribuyó al rechazo de los partidos.

Los realistas consideraban que la Constitución del Estado no era otra cosa que las antiguas Leyes Fundamentales que expresaban el pacto suscrito por el Rey y el Reino para regular sus respectivos derechos ${ }^{50}$. El contenido de las Leyes Fundamentales estaba protegido por diversos niveles de rigidez constitucional: así, existía un núcleo intangible (integrado por el carácter monárquico del Estado o la confesionalidad de éste); un sector normativo integrado por normas modificables sólo a través del común asenso entre el Rey y el Reino; y, finalmente, normas que podían alterar las Cortes (el Reino) por sí solas. Dentro del entramado constitucional histórico los partidos no encontraban reflejo alguno. La historia castellana, aragonesa y navarra mostraban sólo los ejemplos de agrupaciones estamentales, pero no de asociaciones constituidas con fines políticos. Por consiguiente, los partidos no formaban parte del entramado constitucional.

Los liberales, por su parte, optaron por el modelo racional-normativo que se difundió desde el constitucionalismo norteamericano. La Constitución era resultado del ejercicio del poder constituyente de la Nación, de modo que la historia no determinaba el contenido constitucional ${ }^{51}$. La Constitución contenía, por consiguiente, la manifestación más importante de la voluntad soberana; la voluntad constituyente, que suponía decidir la forma de gobierno que

\footnotetext{
${ }^{50}$ Cfr. Llaneras, Diario de Sesiones, vol. III, núm. 330, 28 de agosto de 1811, pág. 1706; Borrull, ibidem, pág. 1711; Obispo de Calahorra, ibídem, pág. 1712-1713; Llamas, ibídem, pág. 1714; Inguanzo, ibídem, pág. 1723; Aner, Diario de Sesiones, vol. iv, 18 de enero de 1812, págs. 2651-2652.

${ }^{51}$ Cfr. a modo de ejemplo Conde De Toreno, Diario de Sesiones, vol. III, núm. 330, 28 de agosto de 1811, pág. 1714-1715; id., vol. iv, núm. 471, 17 de enero de 1812, págs. 2644-2645; Muñoz Torrero, DS, vol. III, núm. 330, 28 de agosto de 1811, pág. 1725; CanEJA, ibídem, pág. 2645.
} 
debía regir la sociedad. Ahora bien, el concepto mismo de voluntad general obstaculizaba la idea de partido.

En efecto, para los liberales la voluntad general no sólo se determinaba en un sentido cuantitativo (por el número de sus destinatarios —igualdad formal_, y por proceder de «toda» la Nación — participación política), sino también en sentido cualitativo: generalidad equivalía a lo mejor para la Nación. El concepto de voluntad general venía así a sustituir a la idea de «felicidad nacional» o de «bienestar público» ${ }^{52}$. El proceso discursivo en las Asambleas servía para alcanzar esa voluntad general; mediante el «intercambio recíproco de luces» los representantes llegaban a descubrir (en un proceso que se consideraba más epistemológico que decisionista) lo más adecuado para la Nación. El resultado de la votación se presuponía que expresaba esa celsitud; de este modo, quien votaba en contra no representaba una opción legítima, sino que, simplemente, se había equivocado en su interpretación de lo que convenía más a la Nación soberana $^{53}$.

El resultado de cuanto acaba de decirse es evidente: para los liberales no podía existir una oposición legítima, puesto que cuanto se expresaba en el Parlamento era voluntad soberana e indiscutible. Lo contrario no era sino voluntad errada; manifestación de intereses parciales y no expresión de lo más apropiado para la Nación. Por tanto, el partido, basado en el pluralismo político, y en el valor de todas las opciones políticas, no podía concebirse bajo el prisma liberal.

La Constitución era, como se ha dicho, la expresión de la voluntad general constituyente. En consecuencia, como decía Argüelles, sancionado un artículo constitucional su contenido dejaba de ser opinable, para convertirse en la sola voluntad de la Nación ${ }^{54}$. Precisamente la más relevante referencia a los partidos en las Cortes de Cádiz tuvo lugar para poner de manifiesto esta idea. Así, Miguel Riesco, diputado por Chile, manifestó que, a diferencia de las Constituciones francesa y sueca («obras de una facción, concebidas en horas, aceptadas en minutos y destruidas cuando lo era el partido que las había procurado»), el texto gaditano era expresión de una unidad de voluntad nacional: «uno es el interés, uno el partido, una, pues, la opinión ${ }^{55}$.

\footnotetext{
${ }^{52}$ Sobre la evolución de estos conceptos vid. por todos Philippe Roger, Voz «Felicidad», en Vicenzo Ferrone/Daniel Roche (ed.), Diccionario histórico de la Ilustración, Madrid, Alianza, 1998, págs. 48-55.

${ }^{53}$ Vid. Jean-Jacques Rousseau, Du contrat social (1762), Paris, Bordas, 1972, Livre iv, Chapitre II, pág. 186.

${ }^{54} D S$ n $^{\circ} 620,28$ de julio de 1812 , vol. V, pág. 3478.

${ }^{55} \mathrm{DS} \mathrm{n}^{\circ}$ 474, 20 de enero de 1812, vol. IV, pág. 2666. En un sentido aproximado afirmaba Argüelles: «No es tan fácil que en las Cortes se formen esos paridos o facciones que tanto se abultan para emprender reformas perjudiciales». DS (Cortes extraordinarias 1810-1813), núm. 362, 29 de septiembre de 1811, vol. III, pág. 1952.
} 
A fin de dar estabilidad a la Constitución, los liberales dotaron al texto de 1812 de una rigidez temporal absoluta (art. 375, donde se establecía que hasta pasados ocho años no podría acometerse ninguna reforma constitucional). El fundamento liberal de la rigidez de la Constitución era muy distinto del realista: para los realistas era un producto de la historia, consecuencia de su concepción estática del Derecho; para los liberales era un producto racional, aunque el Derecho Natural imponía parte de estos límites (como la división de poderes, o el reconocimiento de derechos subjetivos). Sin embargo, las consecuencias de la rigidez para la exclusión de los partidos eran idénticas. En efecto, al dotar a la Constitución de una rigidez absoluta cualquier opción contraria (republicana, aconfesional, absolutista...) no tenía posibilidades de prosperar y se consideraba fuera del sistema ${ }^{56}$. Determinadas cuestiones quedaba, pues, fuera de toda discusión; en el caso de los liberales sujeta a plazo, en el caso de los realistas de forma definitiva.

\subsection{La repercusión de la forma de gobierno en la ignorancia del partido}

Según se ha visto, la idea de los derechos y de la Constitución impedía percibir los partidos políticos en la sociedad. La idea que sostuvieron liberales y realistas sobre la forma de gobierno nacional repercutió, a su vez, en la negación del partido como realidad dentro del Parlamento (Grupos Parlamentarios).

Los realistas admiraban el sistema británico de gobierno como lo habían descrito Montesquieu, De Lolme, Locke, Hume o Blackstone. Estos autores describían un régimen basado en la idea de equilibrio constitucional, tal cual establecía el statute law, pero sin apreciar las modificaciones operadas a través de las convenciones constitucionales. Por tanto, los realistas no tuvieron sino una visión distorsionada de Inglaterra, identificándola con una Monarquía Constitucional equilibrada, y no con un sistema parlamentario de gobierno ya en ciernes. El éxito de esta imagen distorsionada entre los realistas se debía a que se compatibilizaba con la anacrónica teoría del gobierno mixto. En ambos casos

\footnotetext{
${ }^{56}$ Precisamente esta circunstancia la percibió con agudeza el diputado Guridi y Alcocer, utilizándola como argumento para atacar la cláusula de intangibilidad. Para el diputado americano la Constitución debía ser reformable para que aquellos que tuvieran intereses contrarios a su articulado pudiesen en el futuro introducir las enmiendas que estimasen convenientes. Guridi y Alcocer, frente a las opiniones liberales, consideraba que la Constitución, al haberse formado sin la guía unificadora que era el Monarca, había sido realizada con «conflicto de intereses, divergencia de las opiniones y división de facciones y partidos». DS (Cortes extraordinarias de 1810-1813), núm. 472, 18 de enero de 1812, vol. iv, pág. 2656. Precisamente Argüelles argüía, en sentido contrario, que la rigidez constitucional pretendía evitar que una facción reformase la voluntad constituyente. DS (Cortes extraordinarias de 1810-1813), núm. 361, 28 de septiembre de 1811, vol. III, pág. 1947.
} 
se trataba de lograr un equilibrio entre los poderes del Estado, si bien la teoría del gobierno mixto presuponía una base social a éstos.

En coherencia con estas ideas, los realistas trataron de establecer un gobierno en el que el Monarca asumiese personalmente las funciones estatales más relevantes, ejerciendo el poder ejecutivo y participando del legislativo mediante el veto. Los ministros quedaban relegados a meros Secretarios del Despacho del Rey, denominación más exitosa entre los realistas. A fin de lograr un equilibrio constitucional adecuado, el Parlamento se dividiría en dos Cámaras, correspondiéndole a la Alta (compuesta por nobleza y clero), mediar entre la Cámara Baja y el Monarca. Este hábil juego de controles mutuos y contrapesos sociales y políticos excluía la presencia de los partidos. Por una parte, el poder ejecutivo correspondía al Rey, no a los ministros, con lo que no había lugar a que se formase un «partido ministerial» que apoyase la política del Gobierno ${ }^{57}$. Por otra parte, el Parlamento era expresión de la composición estamental de la sociedad (la Cámara Baja del pueblo, y la Alta del clero y nobleza) en la que, según ya se ha visto, no se admitían otras asociaciones.

El bicameralismo apadrinado por los realistas servía, por tanto, para impedir la formación de partidos o, al menos, para impedir que estos pudieran imponerse. El elemento democrático del régimen tendía al tumulto y a la formación de facciones que acababan imponiéndose mediante artimañas demagógicas. El elemento aristocrático, caracterizado por la virtud y moderación (como apuntaban Montesquieu y Blackstone) serviría para compensar esas facciones, asegurando mediante una segunda reflexión pausada que las leyes fuesen fruto del raciocinio, y no de la precipitación.

La forma de gobierno que los liberales lograron plasmar en la Constitución de 1812 respondía a premisas muy distintas, basadas en el modelo francés de 1791, y no en el británico. Este modelo también se separaba del sistema parlamentario de gobierno, estableciendo un sistema de separación de poderes rígida en la que, sin embargo, el Parlamento absorbía las competencias más relevantes en virtud de su carácter de representante de la Nación soberana. Al Rey todavía le quedaban algunas funciones relevantes (como la declaración de la gue-

${ }^{57}$ Como excepción ha de señalarse que el periódico realista El Procurador General publicó un artículo firmado bajo el seudónimo de «El Celtíbero», en el que se proponía cambiar la denominación de «liberales» y «serviles» por la de «ministeriales» y «antiministeriales». El Procurador General de la Nación y del Rey, núm. 176, 25 de marzo de 1813, pág. 1445. Sin embargo, el autor no profundizaba en las razones de esta distinción, cuando los ministros todavía no ocupaban un papel relevante en el Estado. En esos momentos la distinción, en su caso, sería entre los partidarios y los detractores de la cuarta Regencia (integrada por Pedro Agar, Gabriel Ciscar y Luis de Borbón desde el 8 de marzo de 1813), que contaba con el apoyo de los liberales y el rechazo de los realistas, quienes habían visto caer a la Regencia Constitucional, mucho más afín a su ideario. 
rra o el nombramiento de cargos públicos), pero básicamente se lo concebía como el titular de un poder ejecutivo que ejercía personalmente y sin la presencia de un Gobierno.

Los liberales partieron de una visión dicotómica entre el Ejecutivo y el Legislativo, al concebir que el primero expresaba el Estado limitador, y el segundo la garantía de los derechos. Esta confrontación estaba concebida en términos binarios e interorgánicos: la confrontación se manifestaba entre el Rey y el Parlamento, sin admitir en este último la división entre mayoría y oposición. Algo que estaba también favorecido por la idea de la Nación representada, concebida en términos unitarios y desconociendo, por tanto, el pluralismo social. En definitiva, al desconocer el sistema parlamentario de gobierno, los liberales desconocían también la bipolarización dentro del Parlamento entre mayoría gubernamental y minoría opositora. El Parlamento, concebido como unidad, siempre era todo él «oposición al Ejecutivo», porque sólo así las libertades individuales gozaban de salvaguardia. 